

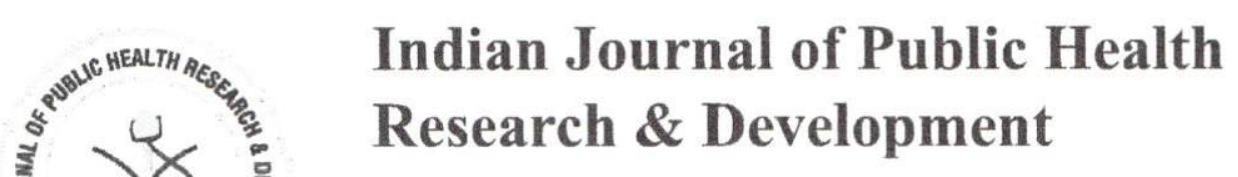

www.ijphrd.com

\section{Contents}

Volume 11, January 01

January 2020

1. Study Protocol: A Randomised Controlled Trial on Effectiveness of a Worksite Health Intervention on Common Musculoskeletal Problems and Work-Related Quality of Life (WRQoL) among Female Workers in the Garment Manufacturing Sectors.

A. Santham Lilly Pet, Timsi Jain, Bobby Joseph, Pethuru Devadason, Gayathri M

2. Health of the Elderly in India: A Socio-Legal Study

Arti, J.K. Mittal

3. General Awareness of Diabetes Mellitus among a Hospital Population in Chennai: A Survey Sridhar M., Abilasha Ramasubramanian

4. Vitamin D Deficiency in Rural Area of Gautam Buddh Nagar: An Observational Study..... Vijay Deepak Verma, Ajai Kumar Garg, Suresh Babu, Ashish Satyarthi

5. Identifying the Status of Menstrual Hygiene Management Amrita Shilpi, Rajasree Roy, Gobina, Spriha Roy

6. Effect of Strengthening of Scapular Stabilizers in Treatment of Rounded Shoulder Posture in Dental Students

Ankita M. Patil, Sayali Gijare

7. Elder Abuse in Indian Setting-A Misconception or a Reality-A Deductive Analysis

Anusha Rashmi, Linda Sequeira, Prianka Shashi Kumar, Rashmi

8. A Study on Women Entrepreneurs Dealing Through Stress.....

Archana R.V., K. Vasanthi Kumari

9. Effect of Bilateral Scapular Muscles Strengthening on Dynamic Balance in Post Stroke Individuals. .38 Arpan Dhoka, G. Varadharajulu

10. In Vitro Antibacterial and Anticancer Study of Bioactive Compounds Isolated from Punica Grantum Peel..45 Arunava Das, J. Bindhu, M. Bharath, Nithin Johnson, M. Jeevanantham

11. A Study on Utilization of Primary Health Care Services among the People Residing in a Semi-Urban Area53

B. Charumathi, D. Jayashri, S. Manisha, Aadithya, C. Hemanthkumar, Timsi Jain

12. An Empirical Relationship between Stress and Job Performance: A Study with Private School Teachers ....57

* D.S. Premalatha, S. Subramanian 
261. Antibacterial Effect of the Combination of Probiotic Milk and Calliandra Honey against Streptococcus Mutans that Causes Tooth Cavities 1402

Uswatun Chasanah, Isnaeni, Nuzul Wahyuning Dyah

262. Reproductive Health Behavior of Street Youth Guided by Karya Putra Indonesia Mandiri Foundation in Central Jakarta Region

Prihavati, Hansrizka Raisna, Ridwan Amiruddin, Owildan Wisudawan B.

263. Trend of Malaria Cases in Maluku Province 2012-2016

Prisilia Oktaviyani, Budi Hartono, Ranti Ekasari

264. A Qualitative Study: Perceptions of Premarital Sexual Behavior among Teenage Girls.

Mia Fatma Ekasari, Eros Siti Suryati, Raden Siti Maryam, Ahmad Jubaedi, Rosidawati, Tien Hartini, Santun Setiawati

265. Hazard and Risk Analysis by Implementing Hiradc Method in the Laboratory of Medical-Surgical at Faculty of Nursing Universitas Airlangga.....

Radhia Maya R.P., DaniNasirul H., PutriAyuni Alayyannur, Tjipto Suwandi, Rizky Agung Firnando

266. A Three-Years Survival Rates of Chronic Myeloid Leukemia Patients with Targeted Therapy

Rani Silondae, Tutik Harjianti, Sahyuddin Saleh, Syakib Bakri, A. Makbul Aman, Hasyim Kasim, Haerani Rasyid

267. The Effect of Alkaloid Extract of Teucrium Polium L. Against Some Pathogenic Bacteria of Urinary Tracts and on Pyelonephritis Induced in Rats

Rawa'a A. Kushaish, Bushra A.M. AL-Salem, Monayed A. Hussein

268. A Study of Complications of Infants of Diabetic Mothers in Babylon Teaching Hospital for Maternity and Pediatrics.

Rebee Mohsin Al-Ithary

269. The Relationship between Obesity and Dyslipidemia in Adolescents

Ria Qadariah Arief, Ridwan Amiruddin, Syamsiah Russeng, Citra Kesumasari, Nurhaedar Jafar, Ummu Salamah, Nugrahaeni

270. The Individual Factor and the Quality of Building's Physical Environment in Correlation with the Occurrence of Sick Building Syndrome (SBS) on Employees of PT. Telkom Jember

Rizki Adi Sulistyanto, Ragil Ismi Hartanti, Prehatin Trirahayu Ningrum, Abdul Rohim Tualeka

271. Public Knowledge on Over the Counter Analgesics at Private Pharmacy Store in Makassar City Indonesia

Rizqi Nur Azizah, Hendra Herman

272. Effect of Different Levels of Coriandrum Sativum and Piper Nigrum and their Interaction on Production, Biochemical Parameter, Liver Enzymes, TSH and Growth Hormone for Broiler Chickens ... 1468 S.G. Hussein, H.Q. Baker

273. Parental Style and its Relation to Adolescents' Self-Concept and Depression. 1474 Safaa Mohammed Zaki, Manal Hassan Abo Elmagd, Nagat Farouk Abo Elwafa 


\title{
Antibacterial Effect of the Combination of Probiotic Milk and Calliandra Honey against Streptococcus Mutans that Causes Tooth Cavities
}

\author{
Uswatun Chasanah ${ }^{1}$, Isnaeni ${ }^{1}$, Nuzul Wahyuning Dyah ${ }^{1}$ \\ 'Department of Pharmaceutical Chemistry, Faculty of Pharmacy (60286), \\ Universitas Airlangga, Surabaya, Indonesia
}

\begin{abstract}
Background: Streptococcus mutans is a Gram-positive bacterium found in the oral cavity. As a cariogenic bacterium, Streptococcus mutans can cause dental caries through its ability to produce an acidic environment that can demineralize tooth structures so that the tooth layer is destroyed.

Objective: To determine the optimal combination of probiotic milk Lactobacillus paracasei and calliandra honey which has antibacterial activity in Streptococcus mutans bacteria.

Method: This study uses diffusion method on Nutrient Agar media. The study began with an examination of the physical properties of probiotic milk and calliandra honey including color, odor, taste, $\mathrm{pH}$, specific gravity and viscosity. Antibacterial activity was indicated by the diameter of the Zone of inhibition ( $\mathrm{mm})$ in the form of clear areas around the well on the media so that containing Streptococcus mutans inoculums $0.25 \mu \mathrm{l} / \mathrm{ml}$.
\end{abstract}

Result: The combination of probiotic milk Lactobacillus paracasei and $50 \%$ calliandra honey solution produced the highest activity at a ratio of $8: 2$ with Zone of inhibition diameters of $16.40 \pm 0.71 \mathrm{~mm}$

Conclusion: The combination of probiotic milk and calliandra honey with 5\% concentration and 8: 2 ratio has the highest antibacterial activity against Streptococcus mutans that causes tooth cavities

Keywords: Streptococcus mutans, antibacterial activity, probiotic milk, Lactobacillus paracasei, calliandra honey.

\section{Introduction}

Streptococcus mutans is a normal flora in the oral cavity that can turn into a pathogen when there is an excessive number colonies ${ }^{(1)}$. Streptococcus mutans is an anaerobic bacterium that is known to produce lactic

\author{
Corresponding Author: \\ Isnaeni \\ Department of Pharmaceutical Chemistry, Faculty of \\ Pharmacy (60286), Universitas Airlangga, Surabaya, \\ Indonesia \\ e-mail: isnaenisurabaya@yahoo.com \\ Contact No.: +6281999201024
}

acid as part of its metabolism and is able to attach to the tooth surface in the presence of sucrose which causes caries in the teeth ${ }^{(2)}$. Streptococcus mutans produces lactic acid through a homo-fermentation process, forming colonies that are firmly attached to the tooth surface and more acidogenic than other species so that it can cause demineralization of tooth enamel at a critical $\mathrm{pH}$ of 5.5. Continuous tooth enamel demineralization will cause dental caries ${ }^{(3)}$.

Several studies show that probiotic bacteria have an influence in the ecology of the oral cavity. There are several strains of probiotic bacteria that have a positive effect in reducing the number of Streptococcus mutans in the saliva of the human oral cavity, namely the acidogenic class of Lactobacillus and Bifidobacterium ${ }^{(4)}$. 
The combination of Lactobacillus paracasei and Bifidobacteriumlongum isolates was able to inhibit the growth of Streptococcus mutans ${ }^{(5)}$.

In its development, probiotic bacteria are packaged in a probiotic product with added milk to meet the nutritional needs of these bacteria ${ }^{(6)}$. Probiotics have proteolytic and lipolytic enzymes that can make milk as a substrate and produce a variety of energy sources ${ }^{(7)}$.

As an antibacterial agent, probiotic milk and honey have different mechanisms, so that a combination of both can affect both activities Antibacterial activity of combination probiotic milk Lactobacillus paracasei and Calliandra honey in inhibiting the growth of Streptococcus mutans are not known, so it needs to be done research to determine the antibacterial activity of the combination of probiotic milk Lactobacillus paracasei ATCC BAA52 and Calliandra Honey (Calliandracalothyrsus) against Streptococcus mutans in various comparisons ${ }^{(8)}$. Based on this background, this study aims to determine the combination of probiotic milk Lactobacillus paracasei ATCC BAA52 and Calliandra honey (Calliandracalothyrsus) which can provide maximum antibacterial activity against Streptococcus mutans.

\section{Material and Method}

Materialsand Equipments: The materials are Media Nutrient Agar (Oxoid), Agar de Man Ragosa Sharpe (MRS), Calliandra honey from Yogyakarta, milk, $\mathrm{NaCl}$ (Merck), Klindamisin, sterile distilled water and membrane filter with a size of $0.22 \mu \mathrm{m}$. The equipments are analytical scales, glassware, petri dishes, micro pipettes (Socorex), öse wire, ependorf, vortex (Type 161700 mixer), incubator (Memmert), vernier caliper, colony counter, shaker, refrigerator, picnometer, viscosity ostwald, viscosity Cup and Bob, autoclave (HL-340 series sterile vertical type steam), pH meter (Schott glass mainz CG 842 type), laminar air flow cabinet, lactodensimeter, and spectrophotometer (Thermo Fisher Scientific 5225 Verona Road).

Agar well diffusion method: Test bacteria aged 1824 hours are suspended into the agar medium at around $45 \mathrm{oC}$. The bacterial suspension is poured into a sterile petri dish. After the agar becomes solid, holes are made with a diameter of 6-8 $\mathrm{mm}$. Into the hole, a solution of the substance is inserted which will be tested for $20 \mu \mathrm{L}$ of activity, then incubated at $37 \mathrm{oC}$ for 18-24 hours $^{(9)}$.

\section{Results}

Table 1: Observation Result of Zone of inhibition diameter of probiotic milk at various concentrations $(\%)$ on the growth of mutant Streptococcus.

\begin{tabular}{|c|c|}
\hline $\begin{array}{c}\text { Probiotic milk } \\
\text { concentration }\end{array}$ & Zone of inhibition diameter $(\mathbf{m m})$ \\
\cline { 2 - 2 } & Mean $\mathbf{\text { SD }}$ \\
\hline $100 \%$ & $9,92 \pm 0,52$ \\
\hline $80 \%$ & $9,50 \pm 0,36$ \\
\hline $70 \%$ & $9,12 \pm 0,10$ \\
\hline $60 \%$ & $9,07 \pm 0,09$ \\
\hline $55 \%$ & $9,32 \pm 0,08$ \\
\hline $50 \%$ & - \\
\hline $25 \%$ & - \\
\hline Clindamycin $0,01 \mathrm{ppm}$ & $32,33 \pm 0,47$ \\
\hline
\end{tabular}

From these data, it can be seen that the minimum inhibitory concentration is produced by Lactobacillus paracasei probiotic milk at a concentration of $55.00 \%$, which results in an average diameter Zone of inhibition of $9.3 \pm 0.08 \mathrm{~mm}$ and at a concentration of less than $55.00 \%$ there is no Zone of inhibition. The minimum inhibitory concentration was produced by probiotic milk Lactobacillus paracasei at a concentration of $55 \%$ so that for the next combination carried out at the concentration of probiotic milk Lactobacillus paracasei ATCC BAA52 was above $55 \%$.

Table 2: Observation result of Zone of inhibition diameter of calliandra honey at various concentration (\%) against Streptococcus mutans

\begin{tabular}{|c|c|}
\hline $\begin{array}{c}\text { Calliandra Honey } \\
\text { Concentration }\end{array}$ & Zone of inhibition diameter $(\mathbf{m m})$ \\
\cline { 2 - 2 } & Mean \pm SD \\
\hline $50 \%$ & $24,42 \pm 0,42$ \\
\hline $40 \%$ & $23,20 \pm 0,12$ \\
\hline $30 \%$ & $22,28 \pm 0,06$ \\
\hline $25 \%$ & $21,18 \pm 0,12$ \\
\hline $12.5 \%$ & - \\
\hline $6,25 \%$ & - \\
\hline Clindamycin $0,01 \mathrm{ppm}$ & $19,12 \pm 0,01$ \\
\hline
\end{tabular}

From these data, it can be seen that the minimum inhibitory concentration is produced by calliandra honey at a concentration of $25 \%$, which results in an average diameter Zone of inhibition of $21.18 \pm 0.12$ $\mathrm{mm}$ and a concentration less than $25 \%$ there is no Zone of inhibition. Based on the table above, the minimum inhibitory concentration is produced by calliandra honey (Calliandracalothyrsus) at a concentration of $25 \%$, so that the next combination is carried out at the concentration of calliandra honey above $25 \%$. 
Table 3: ZOI diameter observation of Combination of Probiotic Milk and calliandra Honey to Streptococcus mutans

\begin{tabular}{|c|c|c|c|c|}
\hline \multirow{2}{*}{ Combination (Probiotic: Honey) } & \multicolumn{3}{|c|}{ Zone of Inhibition Diameter $(\mathbf{m m})$} & \multirow{2}{*}{ Mean \pm SD } \\
\cline { 2 - 4 } & 1st Replication & 2nd Replication & 3rd Replication & \\
\hline $1: 9$ & 9,20 & 10,00 & 11,00 & $10,07 \pm 0,74$ \\
\hline $2: 8$ & 12,35 & 13,00 & 13,15 & $12,83 \pm 0,35$ \\
\hline $3: 7$ & 11,40 & 12,35 & 13,00 & $12,25 \pm 0,66$ \\
\hline $4: 6$ & 12,35 & 13,10 & 13,10 & $12,85 \pm 0,35$ \\
\hline $5: 5$ & 12,35 & 13,25 & 14,10 & $13,23 \pm 0,71$ \\
\hline $6: 4$ & 13,30 & 14,00 & 14,00 & $13,77 \pm 0,33$ \\
\hline $7: 3$ & 12,30 & 12,35 & 12,35 & $12,33 \pm 0,02$ \\
\hline $8: 2 * *$ & $15,40 * *$ & $16,80 * *$ & $17,00 * *$ & $16,40 \pm 0,71 * *$ \\
\hline $9: 1$ & 15,00 & 15,20 & 16,10 & $15,43 \pm 0,48$ \\
\hline Calliandra Honey & 15,40 & 15,00 & 14,90 & $15,10 \pm 0,35$ \\
\hline Probiotic milk & 14,60 & 13,60 & 12,00 & $13,40 \pm 1,84$ \\
\hline Clindamycin & 21,00 & 21,00 & 21,00 & $21,00 \pm 0,00$ \\
\hline
\end{tabular}

From these data, it can be seen that the maximum ZOI diameter is produced by a combination of $\mathrm{L}$. paracasei probiotic milk and calliandra honey at a ratio of 8: 2 which results in a diameter of the Zone of inhibition greater than the other comparison which is $16.40 \pm 0.71$ $\mathrm{mm}$. The maximum antibacterial activity is indicated by the combination of Lactobacillus paracasei probiotic milk and $50 \%$ calliandra honey at a ratio of $8: 2$ which has the largest Zone of inhibition diameter, then oneway anova statistical test (attachment 10) to determine the difference in diameter significance the average zone of inhibition (ZOI) between each group is presented in Table 4.

Table 4: Differences in ZOI Diameter mean value of Combined Zone of Probiotic L.paracasei and Calliandra Honey against $\mathrm{S}$. mutans according to HSD Test

\begin{tabular}{|c|c|c|c|c|c|c|c|c|c|c|c|c|}
\hline Kel & $1: 9$ & $2: 8$ & $3: 7$ & $4: 6$ & $5: 5$ & $6: 4$ & $7: 3$ & $8: 2$ & $9: 1$ & $\mathrm{M}$ & $\mathrm{S}$ & $\mathrm{K}$ \\
\hline $1: 9$ & & $2,77^{*}$ & $2,18^{*}$ & $2,78^{*}$ & $3,17^{*}$ & $3,70^{*}$ & $2,27^{*}$ & $6,33^{*}$ & $5,37^{*}$ & $5,03^{*}$ & $3,33^{*}$ & $10,93^{*}$ \\
\hline $2: 8$ & $2,77^{*}$ & & 0,58 & 0,02 & 0,40 & 0,93 & 0,50 & $3,57^{*}$ & $2,60^{*}$ & $2,26^{*}$ & 0,57 & $8,17^{*}$ \\
\hline $3: 7$ & $2,18^{*}$ & 0,58 & & 0,60 & 0,98 & $1,52^{*}$ & 0,08 & $4,15^{*}$ & $3,18^{*}$ & $2,85^{*}$ & 1,15 & $8,75^{*}$ \\
\hline $4: 6$ & $2,78^{*}$ & 0,02 & 0,60 & & 0,38 & 0,92 & 0,52 & $3,55^{*}$ & $2,58^{*}$ & $2,25^{*}$ & 0,55 & $8,15^{*}$ \\
\hline $5: 5$ & $3,17^{*}$ & 0,40 & 0,98 & 0,38 & & 0,53 & 0,90 & $3,17^{*}$ & $2,20^{*}$ & $1,87^{*}$ & 0,17 & $7,77^{*}$ \\
\hline $6: 4$ & $3,70^{*}$ & $0,93^{*}$ & $1,52^{*}$ & 0,92 & 0,53 & & $1,43^{*}$ & $2,63^{*}$ & $1,17^{*}$ & $1,33^{*}$ & 0,37 & $7,23^{*}$ \\
\hline $7: 3$ & $2,27^{*}$ & $0,50^{*}$ & 0,08 & 0,52 & 0,90 & $1,43^{*}$ & & $0,97^{*}$ & $3,10^{*}$ & $2,77^{*}$ & 1,07 & $8,67^{*}$ \\
\hline $8: 2$ & $6,33^{*}$ & $3,57^{*}$ & $4,15^{*}$ & $3,55^{*}$ & $3,17^{*}$ & $2,63^{*}$ & $4,07^{*}$ & & 0,97 & $1,30^{*}$ & $3 *$ & $4,60^{*}$ \\
\hline $9: 1$ & $5,37^{*}$ & $2,60^{*}$ & $3,18^{*}$ & $2,58^{*}$ & $2,20^{*}$ & $1,67^{*}$ & $3,10^{*}$ & 0,97 & & $0,33^{*}$ & $2,03^{*}$ & $5,57^{*}$ \\
\hline $\mathrm{M}$ & $5,03^{*}$ & $2,26^{*}$ & $2,85^{*}$ & $2,25^{*}$ & $1,87^{*}$ & $1,33^{*}$ & $2,77 *$ & $1,30^{*}$ & 0,33 & & $1,70^{*}$ & $5,90^{*}$ \\
\hline $\mathrm{S}$ & $3,33^{*}$ & 0,57 & 1,15 & 0,55 & 0,17 & 0,37 & 1,07 & $3 *$ & $2,03 *$ & $1,70^{*}$ & & $7,60^{*}$ \\
\hline $\mathrm{K}$ & $10,93^{*}$ & $8,17^{*}$ & $8,75^{*}$ & $8,15^{*}$ & $7,77^{*}$ & $7,23^{*}$ & $8,67^{*}$ & $4,60^{*}$ & $5,57^{*}$ & $5,90^{*}$ & $7,60^{*}$ & \\
\hline
\end{tabular}

Description: Yellow - Significant different $(p<0,05)$, White No significant different $(\mathrm{p}>0,05), \mathrm{M}-50 \%$ calliandra honey, $\mathrm{S}$ $100 \%$ probiotic milk, $\mathrm{K}$ - Positive control (Clindamycin $0.01 \mathrm{ppm}$ )

Based on Table 4, it is known that there are differences in the average diameter of the ZOI according to TukeyHSD for a ratio of $8: 2$ with other ratio except 9: 1. But the optimal ratio is also determined by the diameter of the zone of inhibition (ZOI) which is the largest among 
the other ratio. So the optimal ratio is shown by the combination of probiotic milk Lactobacillus paracasei and Calliandra honey in a ratio of $8: 2$.

Table 5: ZOI diameters of Probiotic Milk Lactobacillus paracasei and Calliandra honey (Calliandracalothyrsus) combination against Streptococcus mutans

\begin{tabular}{|c|c|}
\hline $\begin{array}{c}\text { Concentration of Probiotic } \\
\text { and Calliandra Honey } \\
\text { Combination (8: 2) }\end{array}$ & $\begin{array}{c}\text { ZOI diameter against } \\
\text { Streptococcus mutans(mm) }\end{array}$ \\
\cline { 2 - 2 } & Mean \pm SD \\
\hline $100 \%$ & $17,13 \pm 0,23$ \\
\hline $50 \%$ & $12,86 \pm 0,15$ \\
\hline $40 \%$ & $11,03 \pm 0,55$ \\
\hline Clindamycin $0,01 \mathrm{ppm}$ & $36,00 \pm 0,00$ \\
\hline
\end{tabular}

From these data, it can be seen that the minimum inhibitory concentration of Streptococcus mutans is produced by a combination of probiotic milk Lactobacillus paracasei and calliandra honey with a ratio of $8: 2$ at a concentration of $40.00 \%$ which is equal to $11.03 \pm 0.55 \mathrm{~mm}$ and at concentrations less than $40.00 \%$ there is no zone of inhibition that generated.

\section{Discussion}

From these results, it was found that probiotic milk Lactobacillus paracasei and calliandra hone had antibacterial activity against Streptococcus mutans at a minimum inhibitory concentration (MIC) of $55 \%$ and $25 \%$. Calliandra honey has smaller MIC than probiotic Lactobacillus paracasei milk which is $25 \%$, so it can be assumed that Calliandra honey is more potent in inhibiting the growth of Streptococcus mutans than Lactobacillus paracasei probiotic milk ${ }^{(10)}$.

From these results, it can be seen that with a decrease in concentration from $100 \%$ to $60 \%$ of Lactobacillus paracasei probiotic milk, there was a decrease in the diameter of the inhibition zone, although at $55 \%$ concentration of probiotic milk Lactobacillus paracasei increased. The results also showed that Lactobacillus paracasei probiotic milk was able to inhibit the growth of Streptococcus mutans at the lowest concentration of $55 \%$ with inhibitory zone diameters of $9.32 \pm 0.08$ $\mathrm{mm}$, because at concentrations below $50 \%$ no inhibition zones were produced.

Based on the research that has been done, the ZOI diameter of probiotic milk Lactobacillus paracasei at a concentration of $100 \%$ is $9.92 \pm 0.52 \mathrm{~mm}$, while at a concentration of $50 \% ; 25 \%$ and $12.5 \%$ do not produce inhibition zones. So that the test is continued at a concentration of $80 \% ; 70 \% ; 60 \%$ and $55 \%$ are produced in succession of inhibitory zone diameters of $9.50 \pm 0.36$ $\mathrm{mm} ; 9,12 \pm 0,10 \mathrm{~mm} ; 9.07 \pm 0.09 \mathrm{~mm}$ and $9.32 \pm 0.08$ $\mathrm{mm}$.

Furthermore, the antibacterial activity of a combination of probiotic milk Lactobacillus paracasei and calliandra honey was carried out to the growth of Streptococcus mutans. In this study, testing was done with agar diffusion method because in the process it is simple, inexpensive and able to test various types of microorganisms and antibacterial agents with easy results of interpretation techniques ${ }^{(11)}$.

According to Ghabanchi in his research, antibacterial activity was shown by the presence of an inhibition zone $(\mathrm{mm})$ in the form of a clear area around the well. The inhibition zone shows that Streptococcus mutans are not resistant to the test solution ${ }^{(12)}$. As a positive control used in testing this antibacterial activity is clindamycin, because the antibiotic is known to be sensitive to gram-positive, facultative anaerobes and has been shown to inhibit the growth of oral bacteria, especially Streptococcus mutans ${ }^{(10)}$.

Based on the research by Bhushan and Chachra (2010), it was said that some probiotic bacteria act as bacteriocin or like inhibitors specifically preventing the growth of cariogenic bacteria, having the ability to protect teeth and affect the growth of supragingival plaques. Adhesion reduction can be an effective way to reduce cariogenic bacteria such as Streptococcus mutans $^{(13)}$.

The effect of osmotic pressure from honey is related to saturated solutions of sugar with water content usually only around $15-21 \%$ of its weight. Solids in honey, $84 \%$ is a mixture of monosaccharides namely fructose and glucose $\mathrm{e}^{(14)}$. The strong interactions between sugar molecules produce water molecules that are not enough for microorganisms. Microorganisms will lose water from this osmosis process and will become dehydrated, so it can kill these microorganisms. Gluconic acid is the most dominant $\operatorname{acid}^{(15)}$. This acid is the result of enzymatic changes in glucose by the glucose oxidase enzyme, which bees secreted from the hypopharyngeal gland becomes a balance between gluconic acid and gluconolactone $^{(16)}$. 


\section{Conclusions}

Based on the results of the study, it can be concluded that the MIC of probiotic milk Lactobacillus paracasei ATCC BAA52 against Streptococcus mutans was $55 \%$. WhiletheMICofcalliandra(Calliandracalothyrsus)honey against Streptococcus mutans is $25 \%$. The combination of probiotic milk Lactobacillus paracasei ATCC BAA52 and Calliandra honey (Calliandracalothyrsus) can provide maximum activity against Streptococcus mutans in a ratio of $8: 2$. The combination MIC of probiotic milk Lactobacillus paracasei ATCC BAA52 and Calliandra honey (Calliandracalothyrsus) against Streptococcus mutanswas $40 \%$.

Ethical Clearance: The research process did not involve with human, instead it is only laboratory research of parasites that is in accordant with the ethical research principle based on the regulation of research ethic committee. The present study was carried out in accordance with the research principles. This study implemented the basic principle ethics of respect, beneficence, non-maleficence, and justice.

Conflict of Interest: The author has not received any conflict of interest so far. It is safe from the conflict

Source of Funding: This study is being conducted all with the author's funds only.

\section{References}

1. Setijanto RD, Puspita AE, Bramantoro T, Wening GRS, Kusumo AD, Rizal MN. Dental communication correlation with felt need profile of dental caries treatment. J Int Oral Heal. 2019;11(7):1.

2. Alfath CR, Yulina V, Sunnati S. Antibacterial Effect of Granati fructus Cortex Extract on Streptococcus mutans In Vitro. J Dent Indones. 2013;20(1):5-8.

3. Kusumaningsih $T$, Subijanto MS, Indrawati R, Devijanti RR. The level of beta defensin- 2 in saliva and its expression in parotid gland epithelial cells after probiotic (Lactobacillus reuteri) induction to inhibit Streptococcus mutans in caries. Eur J Dent. 2016;10(4):556.

4. Chuang L-C, Huang C-S, Ou-Yang L-W, Lin S-Y. Probiotic Lactobacillus paracasei effect on cariogenic bacterial flora. Clin Oral Investig. 2011;15(4):471-6.

5. Truusalu K, Naaber $P$, Kullisaar $T$, Tamm H, Mikelsaar R-H, Zilmer K, et al. The influence of antibacterial and antioxidative probiotic lactobacilli on gut mucosa in a mouse model of Salmonella infection. Microb Ecol Health Dis. 2004;16(4):180-7.

6. Li P, Gatlin III DM. Dietary brewers yeast and the prebiotic Grobiotic ${ }^{\mathrm{TM}} \mathrm{AE}$ influence growth performance, immune responses and resistance of hybrid striped bass (Morone chrysops $\times$ M. saxatilis) to Streptococcus iniae infection. Aquaculture. 2004;231(1-4):445-56.

7. Widyowati R, Agil M. Chemical constituents and bioactivities of several Indonesian plants typically used in jamu. Chem Pharm Bull. 2018;66(5):506-18.

8. Prasetyo R, Safitri E. TOPICAL HONEY TO TREAT AN ABSCESS CAUSED BY STAPHYLOCOCCUS AUREUS: A CASE REPORT. Southeast Asian J Trop Med Public Health. 2018;49(5):835-8.

9. Guess WL, Rosenbluth SA, Schmidt B, Autian J. Agar diffusion method for toxicity screening of plastics on cultured cell monolayers. J Pharm Sci. 1965;54(10): 1545-7.

10. Ghabanchi J, Bazargani A, Afkar MD, Foroshan $\mathrm{SB}$, Ayeen SD. In vitro assessment of antiStreptococcus mutans potential of honey. Iran Red Crescent Med J. 2010;12(1):61.

11. Bogdanov S, Jurendic T, Sieber R, Gallmann P. Honey for nutrition and health: a review. J Am Coll Nutr. 2008;27(6):677-89.

12. Yudaniayanti IS, Primarizky H, Nangoi L. The effects of honey (Apis dorsata) supplements on increased bone strength in ovariectomized rat as animal model of osteoporosis. In: AIP Conference Proceedings. AIP Publishing; 2018. p. 20004.

13. Bhushan J, Chachra S. Probiotics-their role in prevention of dental caries. J Oral Heal Comm Dent. 2010;4(3):78-82.

14. Israili ZH. Antimicrobial properties of honey. Am J Ther. 2014;21(4):304-23.

15. Mufida L, Setijanto RD, Palupi R, Bramantoro T, Ramadhan C, Ramadhani A. Caries and dental and oral hygiene profile of drug (narcotics and dangerous drugs) users at drug rehabilitation centers. J Int Oral Heal. 2019;11(7):6.

16. Ekawati ER, Darmanto W. Lemon (Citrus limon) Juice Has Antibacterial Potential against DiarrheaCausing Pathogen. In: IOP Conference Series: Earth and Environmental Science. IOP Publishing; 2019. p. 12023. 


\title{
Indian Journal of Public Health Research \& Development EXECUTIVE EDITOR
}

\author{
Prof. Vidya Surwade
}

Deptt. of Community Medicine, Dr Baba Saheb Ambedkar, Medical College \& Hospital, Rohini, Delhi

\section{INTERNATIONAL EDITORIAL ADVISORY BOARD}

1. Dr. Abdul Rashid Khan B. Md Jagar Din, (Associate Professor) Department of Public Health Medicine, Penang Medical College, Penang, Malaysia

2. Dr. V Kumar (Consulting Physician) Mount View Hospital, Las Vegas, USA

3. Basheer A. Al-Sum, Botany and Microbiology Deptt, College of Science, King Saud University, Riyadh, Saudi Arabia

4. Dr. Ch Vijay Kumar (Associate Professor) Public Health and Community Medicine, University of Buraimi, Oman

5. Dr. VMC Ramaswamy (Senior Lecturer) Department of Pathology, International Medical University, Bukit Jalil, Kuala Lumpur

6. Kartavya J. Vyas (Clinical Researcher) Department of Deployment Health Research, Naval Health Research Center, San Diego, CA (USA)

7. Prof. PK Pokharel (Community Medicine) BP Koirala Institute of Health Sciences, Nepal

\section{NATIONAL SCIENTIFIC COMMITTEE}

1. Dr. Anju D Ade (Professor) Community Medicine Department, SVIMS, Sri Padamavati Medical College,Tirupati, Andhra Pradesh.

2. Dr. E. Venkata Rao (Associate Professor) Community Medicine, Institute of Medical Sciences \& SUM Hospital, Bhubaneswar, Orissa.

3. Dr. Amit K. Singh (Associate Professor) Community Medicine, VCSG Govt. Medical College, Srinagar - Garhwal, Uttarakhand

4. Dr. R G Viveki (Associate Professor) Community Medicine, Belgaum Institute of Medical Sciences, Belgaum, Kamataka

5. Dr. Santosh Kumar Mulage (Assistant Professor) Anatomy, Raichur Institute of Medical Sciences Raichur(RIMS), Karnataka

6. Dr. Gouri Ku. Padhy (Associate Professor) Community and Family Medicine, All India Institute of Medical Sciences, Raipur

7. Dr. Ritu Goyal (Associate Professor) Anaesthesia, Sarswathi Institute of Medical Sciences, Panchsheel Nagar

8. Dr. Anand Kalaskar (Associate Professor) Microbiology, Prathima Institute of Medical Sciences, AP

9. Dr. Md. Amirul Hassan (Associate Professor) Community Medicine, Government Medical College, Ambedkar Nagar, UP

10. Dr. N. Girish (Associate Professor) Microbiology, VIMS\&RC, Bangalore

11. Dr. BR Hungund (Associate Professor) Pathology, JNMC, Belgaum.

12. Dr Sartaj Ahmad, PhD Medical Sociology, Associate Professor. Swami Vivekananda Subharti University Meerut UP India

13. Dr Sumeeta Soni (Associate Professor) Microbiology Department, B.J. Medical College, Ahmedabad, Gujarat,India

\section{NATIONAL EDITORIAL ADVISORY BOARD}

1. Prof. Sushanta Kumar Mishra (Community Medicine) GSL Medical College - Rajahmundry, Karnataka

2. Prof. D.K. Srivastava (Medical Biochemistry) Jamia Hamdard Medical College, New Delhi

3. Prof. M Sriharibabu (General Medicine) GSL Medical College, Rajahmundry, Andhra Pradesh

4. Prof. Pankaj Datta (Principal \& Prosthodentist) Indraprastha Dental College, Ghaziabad

\section{NATIONAL EDITORIAL ADVISORY BOARD}

5. Prof. Samarendra Mahapatro (Pediatrician) Hi-Tech Medical College, Bhubaneswar, Orissa

6. Dr. Abhiruchi Galhotra (Additional Professor) Community and Family Medicine, All India Institute of Medical Sciences, Raipur

7. Prof. Deepti Pruthvi (Pathologist) SS Institute of Medical Sciences \& Research Center, Davangere, Karnataka

8. Prof. G S Meena (Director Professor) Maulana Azad Medical College, New Delhi

9. Prof. Pradeep Khanna (Community Medicine) Post Graduate Institute of Medical Sciences, Rohtak, Haryana

10. Dr. Sunil Mehra (Paediatrician \& Executive Director) MAMTA Health Institute of Mother \& Child. New Delhi

11. Dr Shailendra Handu, Associate Professor, Phrma, DM (Pharma, PGI Chandigarh)

12. Dr. A.C. Dhariwal: Directorate of National Vector Borne Disease Control Programme, Dte. DGHS, Ministry of Health Services, Govt, of India, Delhi

Print-ISSN: 0976-0245-Electronic-ISSN: 0976-5506, Frequency: Quarterly (Four issues per volume)

Indian Journal of Public Health Research \& Development is a double blind peer reviewed international journal. It deals with all aspects of Public Health including Community Medicine, Public Health, Epidemiology, Occupationa Health, Environmental Hazards, Clinical Research, and Public Health Laws and covers all medical specialties concerned with research and development for the masses. The journal strongly encourages reports of research carried out within Indian continent and South East Asia.

The joumal has been assigned International Standards Serial Number (ISSN) and is indexed with Index Copernicus (Poland). It is also brought to notice that the journal is being covered by many international databases. The journal is covered by EBSCO (USA), Embase, EMCare \& Scopus database. The journal is now part of DST, CSIR, and UGC consortia.

Website : www.ijphrd.com

(c) All right reserved. The views and opinions expressed are of the authors and not of the Indian Joumal of Public Health Research \& Development. The journal does not guarantee directly or indirectly the quality or efcacy of any product or service featured in the advertisement in the journal, which are purely commercial.

\section{Editor}

Dr. R.K. Sharma

Institute of Medico-legal Publications Logix Office Tower, Unit No. 1704, Logix City Centre Mall Sector- 32, Noida - 201301 (Uttar Pradesh)

Printed, published and owned by

Dr. R.K. Sharma

Institute of Medico-legal Publications Logix Office Tower, Unit No. 1704, Logix City Centre Mall Sector- 32, Noida - 201301 (Uttar Pradesh)

Published at

Institute of Medico-legal Publications

Logix Office Tower, Unit No. 1704, Logix City Centre Mall Sector- 32, Noida - 201301 (Uttar Pradesh) 